\title{
$\mathrm{Fe}-\mathrm{Cr}-\mathrm{Mo}$ 합금 분말의 성형 및 소결특성에 미치는 입도분포 영향
}

\author{
김기봉 $a, b \cdot$ 양상선 ${ }^{a} \cdot$ 김용진 ${ }^{a, *} \cdot$ 박용호 $^{b}$ \\ ${ }^{a}$ 한국기계연구원 부설 재료연구소, ${ }^{b}$ 부산대학교 재료공학과
}

\section{Influence of Particle Size Distribution on Green and Sintered Properties of Fe-Cr-Mo Prealloy Powder}

\author{
Ki-Bong Kim ${ }^{a, b}$, Sangsun Yang ${ }^{a}$, Yong-Jin Kim ${ }^{a, *}$ and Yong-Ho Park ${ }^{b}$ \\ ${ }^{a}$ Korea Institute of Materials Science (KIMS), 797 Changwondaero, Seoungsan-gu, \\ Changwon, Gyeongnam 641-831, Korea \\ ${ }^{b}$ Department of Materials Science and Engineering, Pusan National University, \\ 63 Busandaehak-ro, Geumjeong-gu, Busan 607-735, Korea \\ (Received January 11, 2013; Accepted February 25, 2013)
}

\begin{abstract}
The effect of particle size distribution on green and sintered properties of $\mathrm{Fe}-\mathrm{Cr}-\mathrm{Mo}$ prealloy powder was investigated in this study. For the study, prealloyed Fe-Cr-Mo powders with different particle sizes were mixed as various ratios and cold compacted at various pressure and sintered at $1250^{\circ} \mathrm{C}$ for $30 \mathrm{~min}, 90 \% \mathrm{~N}_{2}+10 \% \mathrm{H}_{2}$ atmosphere in the continuous sintering furnace. The results shows that the powders with large particle size distribution have high compressibility and low ejection force. However the green strength are much less than those with small particle size distribution. Tensile prperties of the sintered specimes with large particles size also have high strength and elongation.
\end{abstract}

Keywords: Powder metallurgy, Compaction, Sintering, High-density, Prealloy, Fe-Cr-Mo

\section{1. 서 론}

분말야금 공정에 의해 제조되는 소결 부품들은 높은 정 밀도를 가지는 성형 금형에서 고속 프레스로 성형되고, 이 를 온도제어가 정밀하게 제어되는 소결로를 이용하여 소 결함으로써, 높은 치수 정밀도를 가지기 때문에 반복적이 며 연속성이 요구되는 대량생산 제품의 제조에 적합하다 $[1,2]$. 또한 부품의 최종형상에 가깝게 성형되어 기계가공 및 재료손실을 최소화하거나 삭제 시킬 수 있으며, 상온이 나 대기압 상태에서 원재료분말의 단순 혼합에 의해 성분 이 조절되고 필요에 따라 복합재료, 무공해 재료 및 용해 시 편석을 일으키는 재료들도 자유롭게 사용할 수 있다. 그리고 접합, 표면처리, 열처리 등 다양한 후공정을 추가 하여 고기능 복합형상 제품을 제작할 수 있다는 장점 등 이 있다[3].

일반적으로 자동차용 소결부품의 성능개선을 위해서는
소결재의 고밀도화가 필수적인데 철계 소결소재는 대부분 고상소결공정에 의해 제조되기 때문에 소결 후 기공이 존 재하고 이는 기계적 특성을 저하시키는 원인이 된다. 이에 따라 고밀도 철계 소결소재를 얻기 위해 성형성이 우수하 고 소재로 원가상승을 최소화 시킬 수 있는 $\mathrm{Fe}-\mathrm{Cr}-\mathrm{Mo}$ 계 합금분말을 원료분말로 사용하려 하고 있다[4]. 본 연구에 서는 기존 상용화된 $\mathrm{Fe}-\mathrm{Cr}-\mathrm{Mo}$ 합금분말의 입도분포를 조 절하여 성형성과 소결성에 미치는 영향을 연구함으로서 향후 철계 고밀도 소재를 산업적으로 적용하는데 기초자 료를 확보하고자 한다.

\section{2. 실험방법}

\section{1. 원료분말}

원료분말은 스웨덴 Höganäs사의 Hipaloy 및 Astaloy $40 \mathrm{CrL}$ 분말로 두 분말 모두 $\mathrm{Fe}, \mathrm{Cr}$ 및 $\mathrm{Mo}$ 성분이 동일한

*Corresponding Author: Yong-Jin Kim, TEL: +82-55-280-3527, FAX: +82-55-280-3289, E-mail: yjkim@kims.re.kr 
Table 1. Chemical composition of Hipaloy and Astaloy $40 \mathrm{CrL}$

\begin{tabular}{lccccl}
\hline \hline \multirow{2}{*}{ Powders } & \multicolumn{4}{c}{ Chemical composition (wt.\%) } & \multirow{2}{*}{ Raw powder } \\
\cline { 2 - 5 } & $\mathrm{C}$ & $\mathrm{Mo}$ & $\mathrm{Cr}$ & $\mathrm{Fe}$ & \\
\hline Hipaloy & 0.25 & 0.2 & 1.5 & Bal. & Hipaloy* \\
CrL & 0.25 & 0.21 & 1.48 & Bal. & Astaloy $40 \mathrm{CrL}^{*}$ \\
\hline
\end{tabular}

*Trade mark of sweden Höganäs

조성을 가지며 각각의 분말에 대한 성분은 표 1 에 나타내 었다. Hipaloy 분말은 우수한 성형성을 목적으로 개발된 분말로 수분사공정에 의해 $\mathrm{Fe}, \mathrm{Cr}, \mathrm{Mo}$ 성분이 함유된 합금 분말을 제조한 후, 기계적 강도향상을 위해 흑연을 $0.25 \mathrm{wt} \%$ 혼합한 분말이다[5]. Hipaloy 분말 만으로도 높은 성형압 하에서는 $7.5 \mathrm{~g} / \mathrm{cm}^{3}$ 이상의 높은 성형밀도를 가지는 특성 이 있다. 일반적인 분말야금 공정에서는 분말의 충진도 향 상 및 마찰저감을 통해서 성형성을 향상시키고자 왁스류 의 윤활제 등을 첨가하게 된다. 하지만 이 윤활제들은 일 정 성형압 이상의 높은 성형밀도에서는 외부로 방출되지 못해 성형밀도의 한계를 발생시키는 원인이 되기도 한다. Hipaloy는 $250 \mu \mathrm{m}$ 정도의 균일하며 조대한 분말의 입도를 가지기 때문에 윤활제가 외부로 방출되는 것을 용이하게 하고, 성형 시 압력에 의해 액상으로 변태된 윤활제가 외 부로 방출되어 높은 성형밀도를 가능케 한다. 반면 같이 사용될 또 다른 분말 Astaloy $40 \mathrm{CrL}$ 는 Hipaloy와 동일한 조성을 가진 $\mathrm{Fe}-\mathrm{Cr}-\mathrm{Mo}$ 계 합금분말이며 $0.25 \mathrm{wt} \%$ 의 동일 한 함량의 흑연이 첨가된 분말인데, 분말의 평균입도가 약 $100 \mu \mathrm{m}$ 로 Hipaloy에 비해서는 미세한 분말인 것이 특징 이다. 그림 1 은 레이져 입도분석기를 이용해 측정한 Hipaloy와 Astaloy $40 \mathrm{CrL}$ 분말의 입도분포를 나타내는데 두 분말의 입도 분포차이를 확인 할 수 있다.

\section{2. 성형, 소결 및 특성평가}

본 연구에서는 서로 다른 입도분포를 가진 Hipaloy와

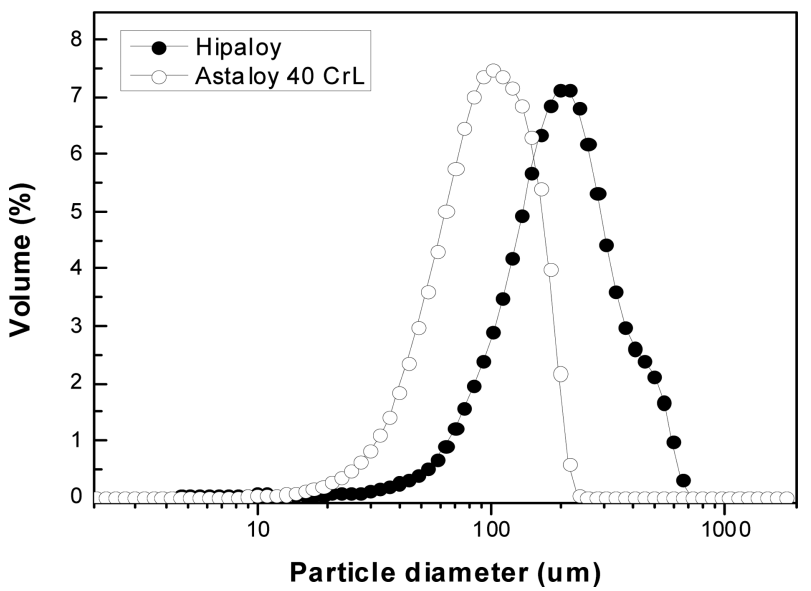

Fig. 1. Particle size distributions of Hipaloy and Astaloy 40CrL.
Table 2. Mixing condition of Hipaloy and Astaloy $40 \mathrm{CrL}$

\begin{tabular}{lcccc}
\hline \hline \multirow{2}{*}{ Materials } & \multicolumn{3}{c}{ Composition (wt.\%) } & \\
\cline { 2 - 4 } & Hipaloy & $\begin{array}{c}\text { Astaloy } 40 \\
\text { CrL }\end{array}$ & ZS1000F & Raw powder \\
\hline HC0 & - & 100 & 0.7 & Hipaloy+CrL \\
HC25 & 25 & 75 & 0.7 & Hipaloy+CrL \\
HC50 & 50 & 50 & 0.7 & Hipaloy + CrL \\
HC75 & 75 & 25 & 0.7 & Hipaloy + CrL \\
HC100 & 100 & - & 0.7 & Hipaloy+CrL \\
\hline
\end{tabular}

*Lubricant

Astaloy $40 \mathrm{CrL}$ 을 비율별로 혼합하여 사용하였으며 분말의 혼합비는 표 2에 나타냈다. 두 종류의 분말에 대한 혼합비 율에 따라서 분말 성형특성의 변화를 측정하였다. 분말의 성형성 측정은 각 분말에 고체윤활제인 ZS1000F를 $0.7 \mathrm{wt} \%$ 포함하여 $\mathrm{V}$ 형 혼합기에서 30 분간로 혼합하여 성형 및 취 출력(Ejection force) 측정이 가능한 만능 성형시험기(KZK Powder Tech. Co)를 사용하였다. 측정방법은 만능 성형시 험기에 장착된 $\phi 8 \mathrm{~mm}$ 금형에서 각각 $490 \mathrm{MPa}, 684$ $\mathrm{MPa}$ 및 $883 \mathrm{MPa}$ 압력으로 성형한 후 성형밀도와 취출력 을 측정하였다. 성형강도(Green strength)측정을 위해 MPIF standard 15에 근거하여 Transverse rupture test(TRS)용 성형용 금형을 이용하여 성형시편으로 제조한 후 3점 굽 힘시험으로 측정하였다.

소결특성을 평가하기 위해서 표 2에 제시된 혼합된 분 말을 80 ton 분말 전용 성형 프레스를 이용하여 $7.15 \mathrm{~g} /$ $\mathrm{cm}^{3} \sim 7.55 \mathrm{~g} / \mathrm{cm}^{3}$ 사이의 밀도로 인장시험편을 성형한 후, $1250^{\circ} \mathrm{C}$ 에서 $90 \%$ 질소와 $10 \%$ 수소의 혼합가스 분위기의 연 속 소결로에서 30 분간 소결하였다.

소결시편의 기계적 특성평가는 Instron 인장 시험기를 이용하여 MPIF standard 10 을 기준으로 인장시험을 하였 다. 한편 시편의 밀도는 성형체의 경우 성형 후 치수 및 무게 측정으로, 소결체는 MPIF standard 42의 아르키메데 스법을 사용하여 측정하였다.

\section{3. 결과 및 고찰}

그림 2는 Hipaloy 및 Astaloy $40 \mathrm{CrL}$ 분말형상을 나타낸 다. Hipaloy는 다양한 분말제조 방법 중 수분사(Water atomization)공정에 의해 제조된 분말이다. 따라서 그림에 서와 같이 분말형상이 매우 불규칙하고 분말표면도 매우 거칠게 나타난다. 일반적으로 분말의 불규칙 형상 및 거친 표면은 성형성에는 나쁜 영향을 미치지만 성형강도 및 소 결성에 있어서는 둥근형상의 매끄러운 표면에 비해 우수 한 특성을 가진다. 또 다른 원료분말인 Astaloy $40 \mathrm{CrL}$ 도 분말의 평균 크기가 Hipaloy보다 작다는 것일 뿐 분말의 

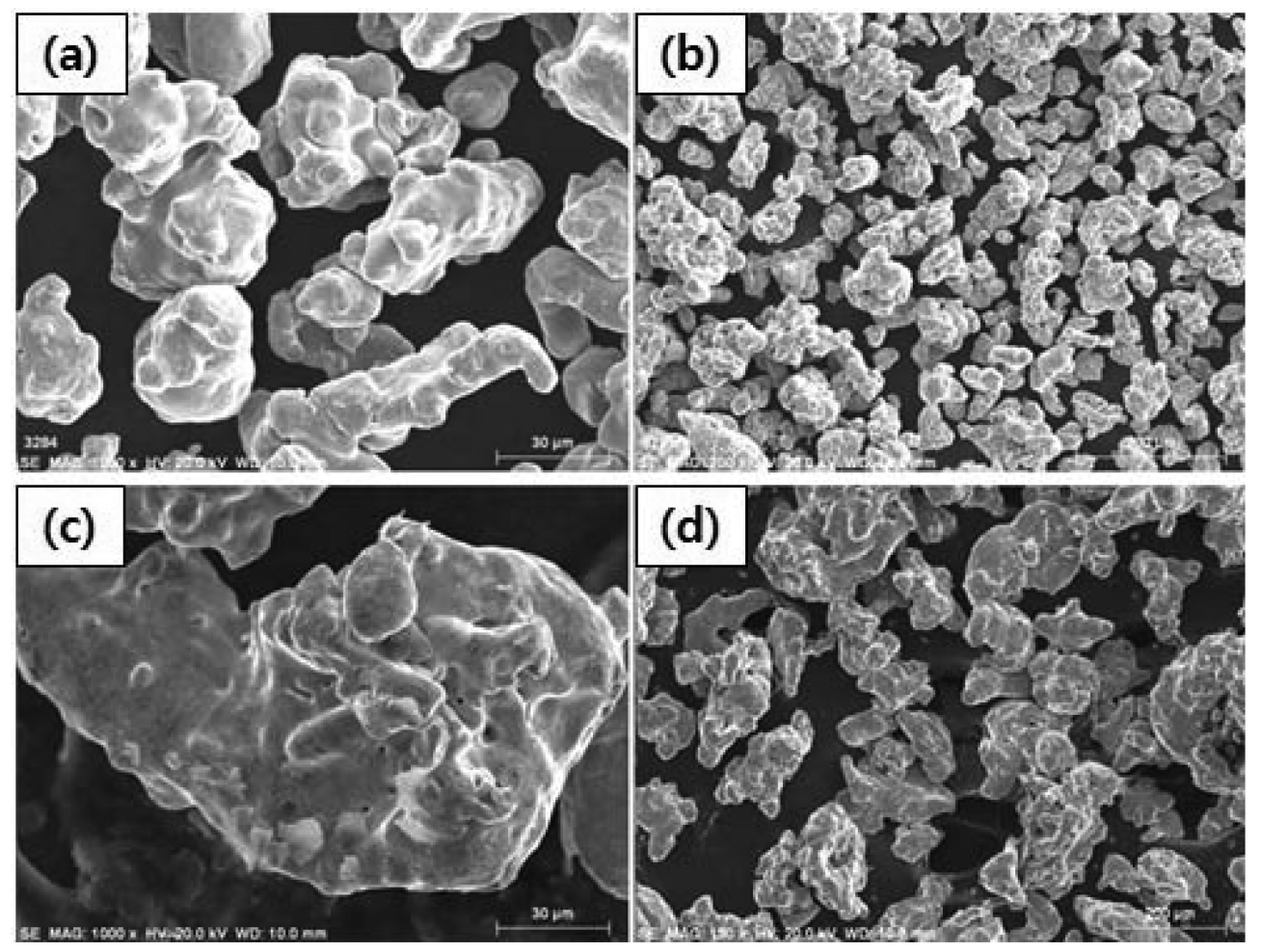

Fig. 2. SEM microgaphs of (a, c) high and (b, d) low magnification of Astaloy 40CrL (a, b) and Hipaloy powders (c, d).

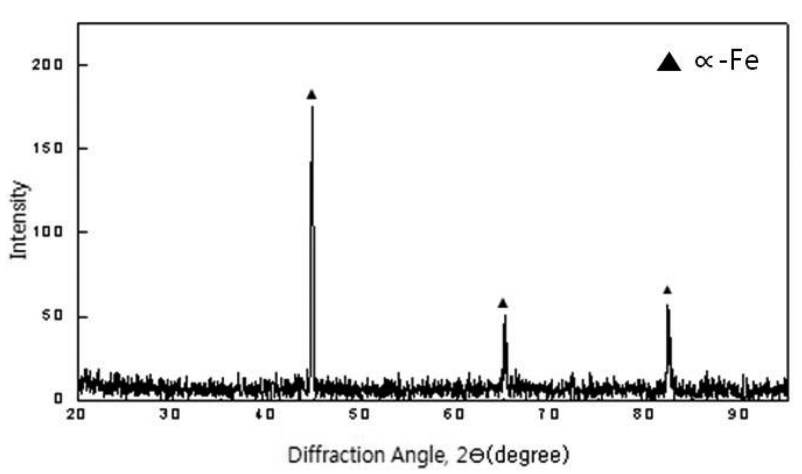

Fig. 3. X-ray diffraction pattern of Hipaloy.

형상은 그림 2와 같게 나타난다. 그림 3은 Hipaloy의 XRD pattern을 나타낸다. 일반적인 철합금 분말에서와 같 이 분말상태에서는 $\alpha-\mathrm{Fe}$ 상만 존재한다는 것을 알 수 있 으며 Astaloy $40 \mathrm{CrL}$ 의 XRD pattern도 그림 3 의 Hipaloy와 동일하게 나타난다.

그림 4는 분말 혼합비가 각각 다른 $\mathrm{HC} 100, \mathrm{HC} 75$, $\mathrm{HC} 50, \mathrm{HC} 25, \mathrm{HC} 0$ 분말의 혼합비 및 성형압력에 따른 성 형밀도를 나타낸다. 그림에서는 동일한 성형압에서도 Hipaloy분말이 많이 포함될수록 성형밀도는 높게 나타난 다. Hipaloy가 포함되지 않은 순수 Astaloy $40 \mathrm{CrL}(\mathrm{HC} 0)$ 분말은 비교적 낮은 성형압인 $490 \mathrm{MPa}$ 의 압력에서 성형 밀도가 $6.0 \mathrm{~g} / \mathrm{cm}^{3}$ 인데 비해, Hipaloy 분말인 $\mathrm{HC} 100$ 의 경 우 $6.6 \mathrm{~g} / \mathrm{cm}^{3}$ 로 $10 \%$ 정도의 높은 성형밀도를 나타낸다. 그

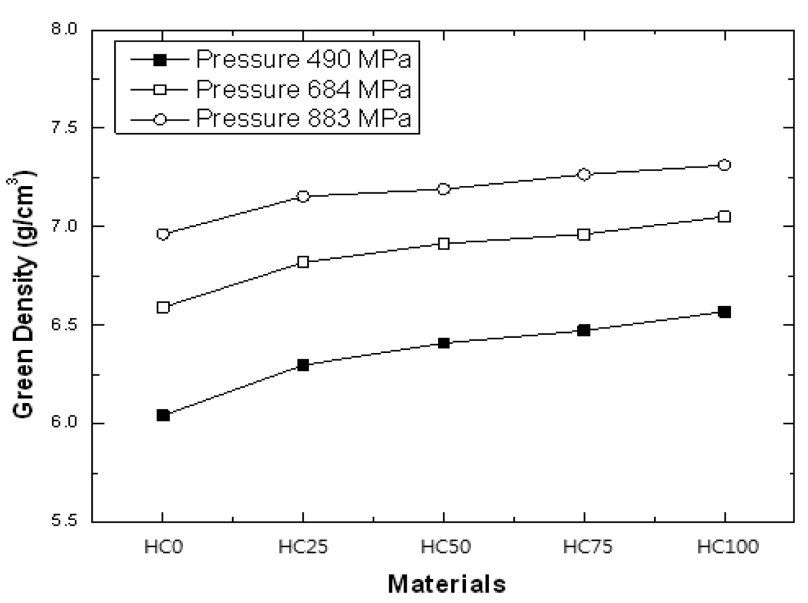

Fig. 4. Compressibility of mixed powder with mixing ratios and compacting pressure at 490, 684 and $883 \mathrm{MPa}$.

러나 성형압이 증가할수록 성형밀도의 차이는 점점 줄어 들어 성형압이 $684 \mathrm{MPa}$ 인 경우 성형밀도차이가 약 $5 \%$ 로 $490 \mathrm{MPa}$ 의 성형압력에서의 차이보다 $50 \%$ 줄었다. 한편 동일한 조성인 분말에서도 성형압에 따라 성형밀도는 크 게 차이가 난다. $\mathrm{HC} 0$ 인 시편에서 성형압 $490 \mathrm{MPa}$ 에서의 성형밀도는 $6.0 \mathrm{~g} / \mathrm{cm}^{3}$ 이며, $684 \mathrm{MPa}$ 에서는 $7.0 \mathrm{~g} / \mathrm{cm}^{3}$ 으로 $16 \%$ 정도의 밀도 증가가 나타난다. 그림 5 는 혼합분말의 혼합비 및 성형밀도에 따른 성형강도를 나타낸다. 그림 5 의 성형밀도 특성과는 달리 성형강도는 동일한 밀도의 경 우 Astaloy $40 \mathrm{CrL}$ 분말이 많이 포함될수록 높게 나타남을 


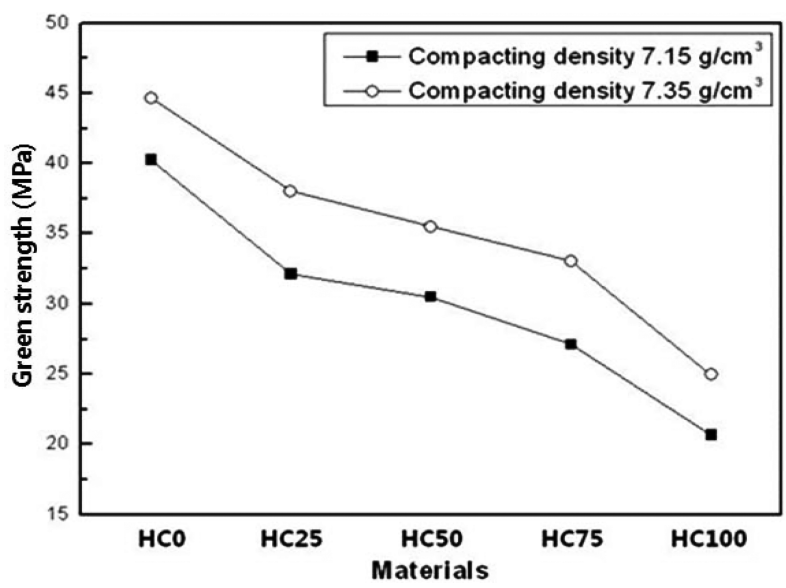

Fig. 5. Green strength of mixied powder with mixing ratios and compacting density at $7.15 \mathrm{~g} / \mathrm{cm}^{2}, 7.35 \mathrm{~g} / \mathrm{cm}^{2}$.

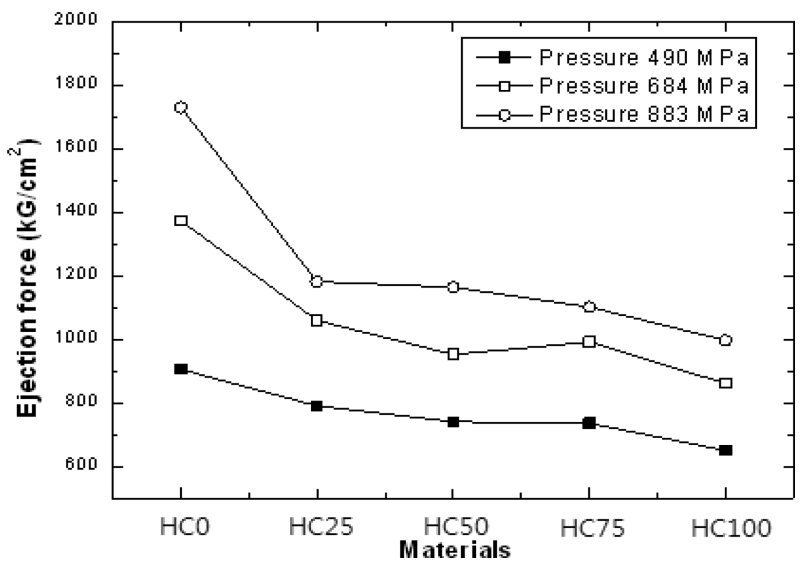

Fig. 6. Ejection force of mixied powder with mixing ratios and compacting pressure at 490, 684 and $883 \mathrm{MPa}$.

알 수 있다. 성형밀도가 $7.35 \mathrm{~g} / \mathrm{cm}^{3}$ 인 성형체의 성형강도 는 순수 Astaloy $40 \mathrm{CrL}$ 분말 $(\mathrm{HC} 0)$ 의 경우 $44.5 \mathrm{MPa}$ 에 이르 는 반면 상대적으로 성형성이 좋게 나타난 Hipaloy( $\mathrm{HC100)}$ 의 경우 $25 \mathrm{MPa}$ 로 상대적으로 $78 \%$ 의 강도차이가 나타난 다. 혼합분말의 경우도 $\mathrm{HC} 50$ 의 경우 $36 \mathrm{MPa}$ 로 $44 \%$ 의 강 도차가 나기 때문에 성형강도 측면에서는 미세한 분말이 많을수록 높게 나타남을 알 수 있다. 그러나 그림 6의 취 출력에 있어서는 미세분말이 많이 포함된 $\mathrm{HCO}$ 의 분말이 성형압력에 무관하게 높은 취출력을 나타낸다. 이는 동일 한 성형압력 하에서 미세분말이 많을수록 금형표면과 접 촉하는 분말의 수가 많아지기 때문에 분말 성형 후 취출 시에 많은 저항을 받기 때문으로 판단된다[6]. 이와 같이 성형성 측면에서는 분말의 평균입도가 증가할수록 성형밀 도는 증가하고 취출력이 낮아지는 반면, 성형강도는 낮게 나타남을 알 수 있다. 따라서 분말 성형 시 성형밀도를 높 혀서 높은 소결밀도를 얻고자 할때는 상대적으로 평균입 도가 큰 분말을 사용하는 것이 유리하지만, 성형강도의 저 하로 인해 매우 복잡하고 정교한 소결부품을 제조할 때에

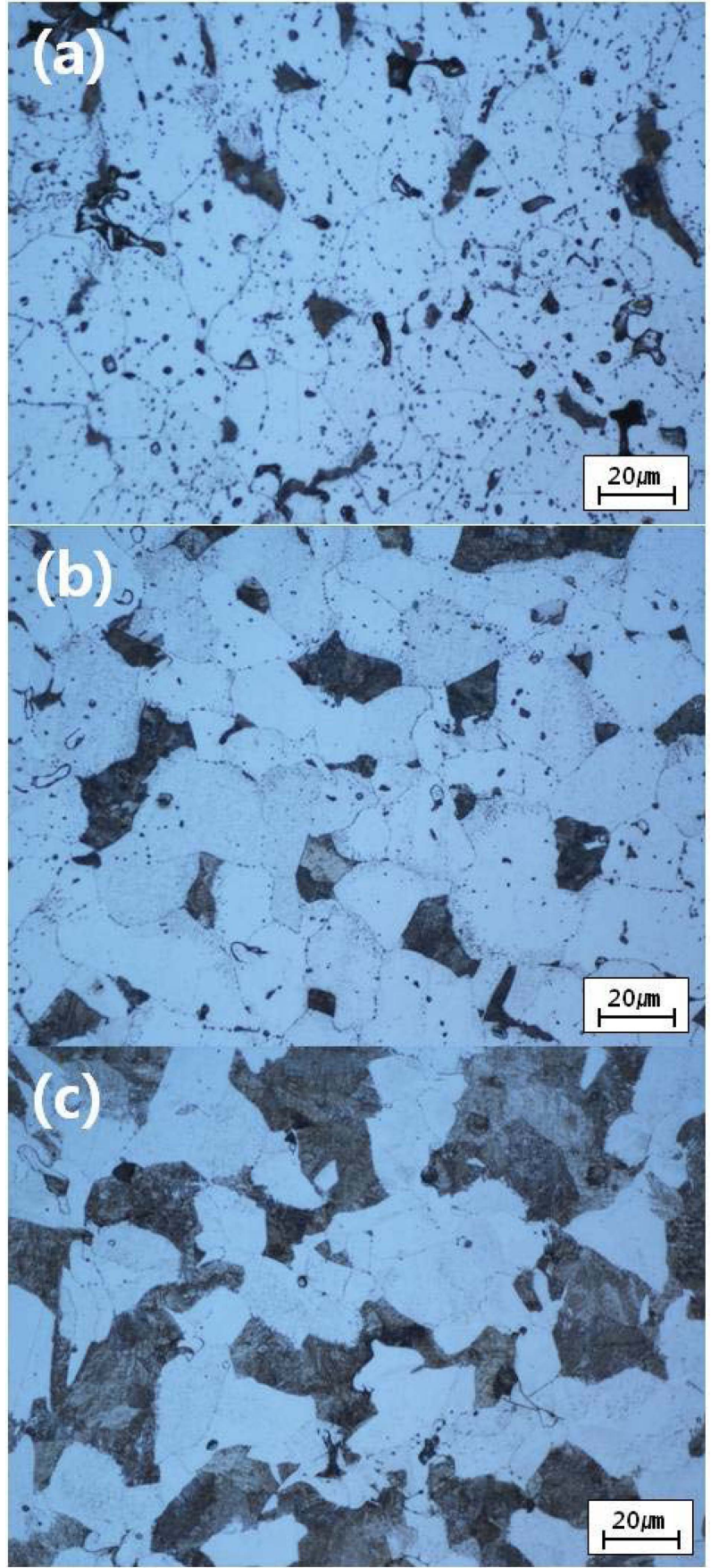

Fig. 7. Microstructures of sintered specimens after sintering at $1250^{\circ} \mathrm{C}$ for 30 min: (a) $\mathrm{HCO}$, (b) $\mathrm{HC} 50$ and (C) $\mathrm{HC} 100$.

는 상대적으로 불리한 측면이 있음을 알 수 있다.

그림 7은 시편에 따른 소결 후의 조직을 나타낸다. Astaloy $40 \mathrm{CrL}$ 분말의 소결조직은 원료분말의 입도가 미 세하기 때문에 소결 후에도 결정립이 미세하게 나타난다. 그러나 다른 시편에 비해 상대적으로 기공도 많이 포함되 어 있음을 알 수 있다. Hipaloy 분말의 함량이 증가할수록 소결조직에서는 결정립의 크기가 증가하고, 이와 함께 기 공도 점차 감소함을 알 수 있다. 한편 소결조직은 흰색의 


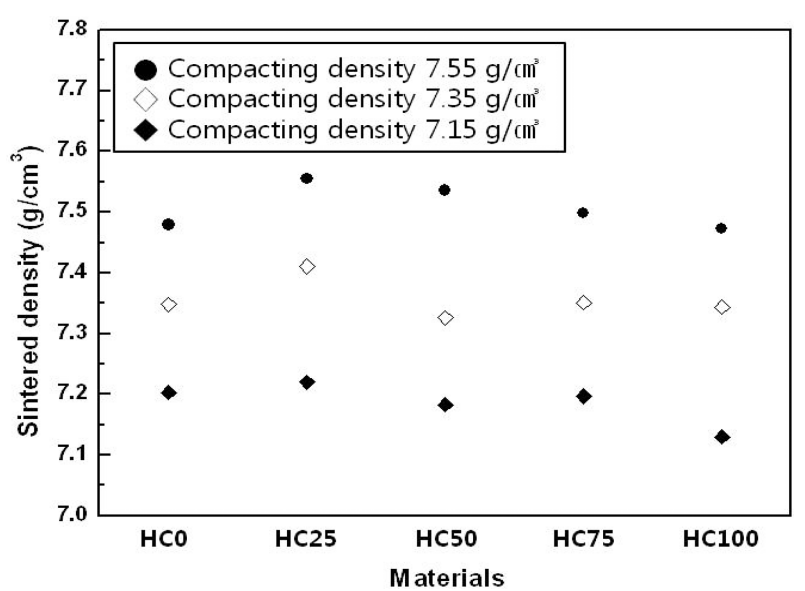

Fig. 8. Sintered density of mixed powder with mixing ratios and compacting density at $7.15,7.35$ and $7.55 \mathrm{~g} / \mathrm{cm}^{3}$.

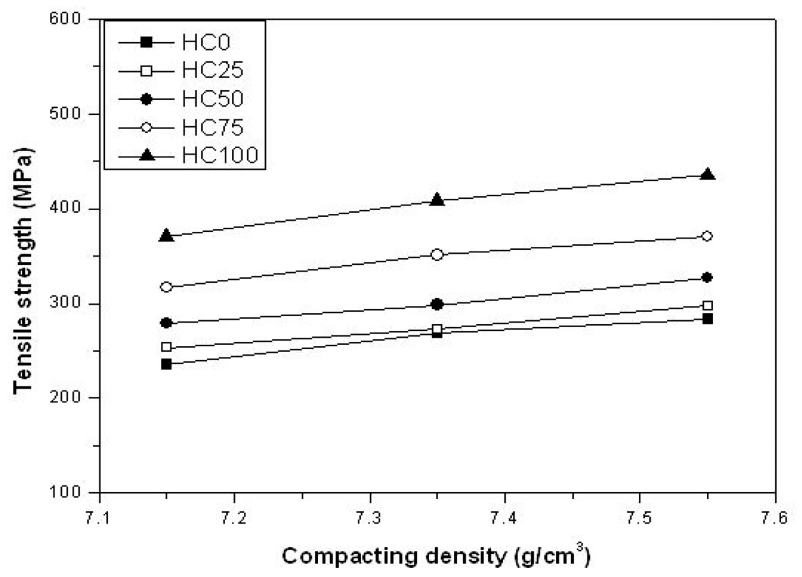

Fig. 9. Tensile strength of mixed powder with compacting density and mixing ratios after sintering at $1250^{\circ} \mathrm{C}$ for $30 \mathrm{~min}$.

페라이트(ferrite)와 회색의 펄라이트(pearlite) 상으로 나타 나는데 펄라이트 상이 차지하는 비율이 Hipaloy 분말이 많을수록 증가됨을 나타낸다. 펄라이트 상의 비율 증가는 탄소함량의 변화를 나타내는데, 초기 원료분말에 포함된 탄소함량이 $0.25 \mathrm{wt} \%$ 임을 고려할 때 소결 중 탄소의 증감 이 발생한 것으로 판단된다.

그림 8은 분말혼합비율과 성형밀도에 따른 소결 후의 밀도변화를 나타낸다. 소결 후 밀도에 있어서는 성형밀도 와 거의 차이가 없게 나타나지만, 성형성이 높게 나타났던 Hipaloy의 경우가 동일한 성형밀도에도 불구하고 약간 낮 게 나타남을 알 수 있다. 또한 높은 성형밀도 영역에서 혼 합분말인 $\mathrm{HC} 25$ 가 상대적으로 약간 높은 소결밀도를 나타 내지만 데이터 상으로 의미있는 증가로 보기는 어렵다. 따 라서 분말혼합비율의 변화가 소결밀도에 미치는 영향은 크지 않음을 알 수 있다. 그림 9은 혼합비율 및 성형밀도 에 따른 $1250^{\circ} \mathrm{C}$ 에서 소결 후의 인장강도를 나타낸다. 동 일한 성형밀도에서는 Hipaloy 분말이 많을수록 인장강도

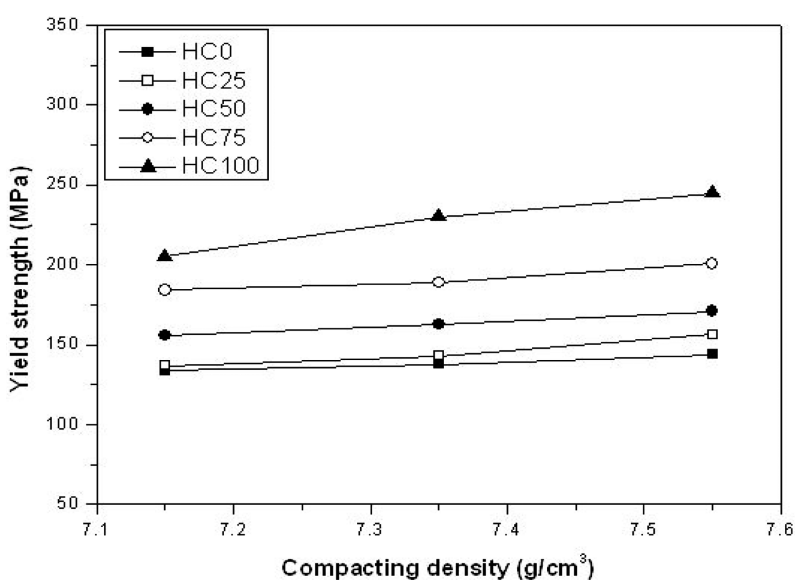

Fig. 10. Yield strength of mixed powder with compacting density and mixing ratios after sintering at $1250^{\circ} \mathrm{C}$ for $30 \mathrm{~min}$.

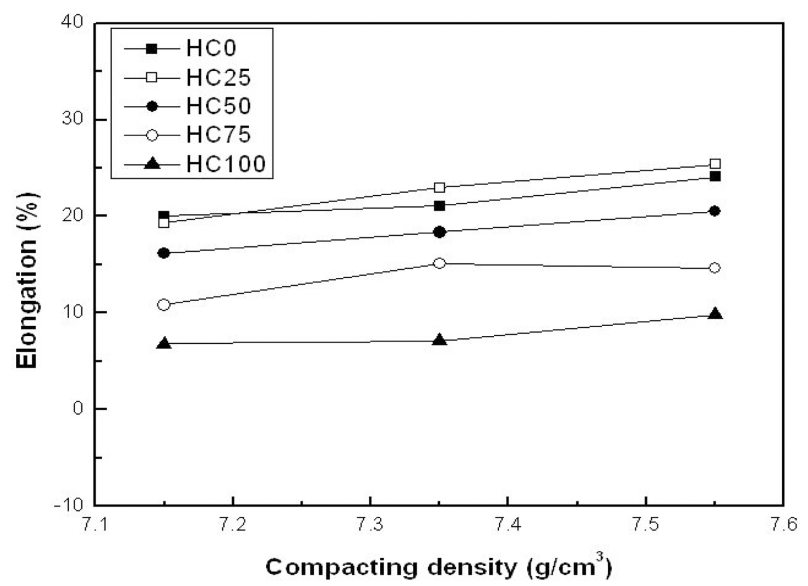

Fig. 11. Elongation of mixed powder with compacting density and mixing ratios after sintering at $1250^{\circ} \mathrm{C}$ for $30 \mathrm{~min}$.

는 증가하고 Astaloy $40 \mathrm{CrL}$ 분말이 $100 \%$ 인 $\mathrm{HC}$ 의 경우 성형밀도 $7.15 \mathrm{~g} / \mathrm{cm}^{3}$ 인 분말에서는 인장강도는 $240 \mathrm{MPa}$ 인 반면에, Hipaloy가 $100 \%$ 인 $\mathrm{HC} 100$ 은 $360 \mathrm{MPa}$ 로 그 차 이가 $120 \mathrm{MPa}$ 에 이르고 있다. 한편 혼합분말에 있어서도 Hipaloy의 혼합비율이 높을수록 인장강도는 점점 증가하 고 있음을 나타내고 동일한 성분에서도 성형밀도가 높을 수록 인장강도가 높아진다. 그림 10 의 항복강도에서도 인 장강도와 같은 현상을 나타낸다. 한편 그림 11 에 나타난 연신율에 있어서도 분말 내에 Hipaloy의 함유량이 증가할 수록 연신율은 증가함을 알 수 있다. 그러나 인장강도 및 항복강도 그림에서 나타난 바와 같이 Hipaloy가 $75 \%$ 포 함된 혼합분말의 경우 순수 Hipaloy 분말과 유사한 연신 율을 나타낸다. 일반적으로 원료분말이 미세하면 소결성 이 증가하고 결정립의 성장이 느려 큰 입자의 분말보다 상대적으로 우수한 기계적 특성을 나타낸다[7]. 그러나 본 연구의 결과에 있어서는 분말의 크기가 클수록 소결밀도 는 유사하지만 기계적 특성이 우수해 진다는 것을 확인할 
수 있었다. 이는 소결 조직상에 나타난 소결 후의 기공과 펄라이트 상의 증가에 의한 것으로 해석되며 이는 분말입 도와 탄소 및 $\mathrm{Cr}$ 성분에 의한 영향이 큰 것으로 판단된다 [8]. 지금까지 철분말에는 강도향상을 위해 $\mathrm{Ni}$ 을 첨가원소 로 많이 사용하여왔다. 그러나 $\mathrm{Ni}$ 원자재의 가격상승에 의 해 $\mathrm{Ni}$ 과 비슷한 효과를 가진 $\mathrm{Cr}$ 을 첨가원소로 적용하기 시작하였다. 하지만 대부분의 소결용 철합금 분말은 공정 비용이 저렴한 수분사공정에 의해 제조되기 때문에 $\mathrm{Cr}$ 원 소는 수분사 중 산화되어 분말에 미세한 산화물 형태로 존재하기 쉽고 이는 성형성 및 소결성에 나쁜 영향을 미 치기는 원인이 된다. 본 연구에서 사용된 원료분말에서도 합금원소로 $\mathrm{Cr}$ 중의 일부는 산화물형태로 존재하며, 특히 분말이 미세할수록 이러한 영향은 크기 때문에 평균입도 가 상대적으로 작은 $\mathrm{HCO}$ 시편에서 소결 후 미세기공이 많 이 관찰되고, 소결 중 탄소에 의한 크롬산화물의 환원효과도 함께 나타나 소결재에서 탄소함량의 변화가 생기고 이로 인 해 펄라이트 상의 비율이 변화하는 것으로 판단된다[9].

\section{4. 결 론}

본 연구에서는 Fe-Cr-Mo계 합금분말의 입도 분포에 따 른 성형 및 소결특성을 관찰하기 위해 동일성분의 각각 다른 입도 분포를 가진 두 종류의 분말을 혼합하여 원료 분말로 사용하였다. 연구결과, 성형성 측면에서는 분말의 평균입도가 증가할수록 성형밀도는 증가하고 성형 후 시 편을 취출할 때의 취출력은 낮아지는 것을 알 수 있었다. 그러나 성형강도 측면에서는 분말입도가 미세할수록 강도 가 높게 나타났다. 한편 소결특성에 있어서는 소결조직은 분말크기가 작을수록 결정립은 미세하였지만, 미세기공이 큰입도를 가진 분말에 비해 상대적으로 많이 함유되어 최
종 기계적 특성은 감소하였다. 또한 소결조직 내 펄라이트 상의 비율도 원료분말의 크기가 클수록 증가하였는데 이 는 원료분말에서 탄소함량이 같지만 분말의 크기나 첨가 원소에 따라 소결 후의 탄소량의 변화가 있음을 나타내고 이는 소결체의 인장특성에 직접적인 영향을 미치기 때문 이다.

\section{감사의 글}

본 연구는 지경부/산업기술연구회의 융합연구사업 일환 인 "마이크로 전자용 $0.1 \sim 10 \mu \mathrm{m}$ 급 미세금속분말 제조 및 부품화기술 개발"의 지원에 의한 것입니다.

\section{참고문헌}

[1] R. M. German: Powder Metallurgy of Iron and Steel, John Wiley and Sons, New York (1997) 29.

[2] A. D. Romin. Jr and M. J. DeHaemer: ASM Handbook Vol. 7 Powder Metal and Technologies and Applications, Peter W. Lee(Ed.), ASM International (1998) 751.

[3] I. Jekins and J. Wood: Powder Metallurgy-an Overview, The Institute of Metal, London (1991) 287.

[4] M. W. Wu, L. C. Tsao, G J. Shu and B. H. Lin: Mater. Sci. Eng. A, 538 (2012) 135.

[5] http://www.hoganas.com/

[6] L Ciripova, E. Hryha, E. Dudrova and A. Vyrostkoba: Mater. Design, 35 (2012) 619.

[7] M. Azadbed and N. G Ahmadi: Curr. Apli. Phys., 9 (2009) 777.

[8] K. S. Narasinham: Mater. Chem. Phys., 67 (2001) 56.

[9] D. Shamugasundaram and R. Chandramouli: Mater. Design, 30 (2009) 3444. 